Young Researchers' section

\title{
An Overview of Gender Equality in Egypt
}

\author{
Hend HASSAN \\ The Bucharest University of Economic Studies, Romania \\ hend.elsaiid@gmail.com
}

\begin{abstract}
Unlike the majority of ancient societies, Egypt held women at a very high eminence rendering them equitable status with men. Ancient Egyptian women possessed equal legal as well as political rights as men, the matter that has been expressed through a lot of Egyptian art and manuscripts. At a certain point in history Egyptian women ruled the country as queens and pharaohs. Unfortunately, moving into the present time the status of women in Egypt shows a profound retreat. Empowering women and incorporating them as vital members and partakers in all realms of life is not a luxury anymore but rather a necessity. Regrettably, gender inequality in Egypt remains to be a fundamental barrier hindering the accomplishment of this goal. It is the aim of this paper to shed light on the current situation of women in Egypt through comparisons with other neighbouring countries as well as with global indices at present. Conclusions show that despite some improvements, a lot remains to be done in order to ensure gender equality that is required to endorse sustainable development goals in Egypt.
\end{abstract}

Keywords: Gender Inequality Index (GII); Global Gender Gap Index (GGI); Sustainable Development Goals (SDGs); Gender Development Index (GDI); Egypt;

JEL Codes: J17; J71; F63; O15;

DOI: http://doi.org/10.24818/ejis.2019.09

\section{Introduction}

Egypt ranks among the highest 10 countries in the world with regards to the gender gap (USAID, 2017). It is essential to realize that by undermining half of the potential workforce we are forgoing half of the human capital diminishing -therefore- both economic growth and economic development. Moreover, recent statistics have revealed that $30 \%$ of the Egyptian households are entirely supported financially by women in addition to an evident percentage co-supporting their families. In 2018 the Central Agency for Public Mobilization has released statistics stipulating that 14\% of Egyptian families are headed by women. Despite that, women in Egypt still lack social, economic, political and legal tools needed to empower them in order to fulfil their vital role in the economy.

The aim of this paper is to shed light on the current situation of women in Egypt through comparisons with their status in the past and with other neighbouring countries as well as with global indices at present. Looking back to the history of Egypt women have been bestowed the highest degree of respect in the society. They have been awarded equitable standing with men in all realms of life, as they enjoyed full social, legal, economic as well as political rights in absence of all forms of gender discrimination. Regrettably, moving into the present time the status of women in Egypt has changed dramatically showing a profound regression. 
Succeeding the introduction, the problem statement and the research methodology are portrayed followed by a short description of the status of women in ancient Egypt. Afterwards, the paper provides an overview of the current status of women in Egypt where some comparisons with neighbouring countries are provided regarding gender gap and gender inequality. The paper also presents the situation of women in the political arena in Egypt as well as their current legal standing. Lastly, the paper concludes that -currentlyEgypt ranks among the highest countries in the world with regards to gender disparity. Bearing in mind that gender equality is at the core of women empowerment, coupled by the wide recognition of the positive correlation between women empowerment and development, it becomes of vital necessity to address the predicament of gender inequality in Egypt. The fact that achieving women empowerment is widely recognized as a prerequisite to development, is patently acknowledged by the Egyptian administration. Despite the sincere exertions of the state however, a lot remains to be achieved in order to bridge the gender gap in Egypt relative to global indices and even to some of its neighbours.

\section{Problem Statement and Research Methodology}

Gender equality in Egypt is a matter of utmost importance, especially because of how it intertwines with attaining Sustainable Development Goals. Egypt ranks among the highest 10 countries in the world with regards to the gender gap (USAID, 2017). It is essential to realize that by undermining half of the potential workforce we are forgoing half of the human capital diminishing -therefore- both economic growth and economic development. Empowering women and incorporating them as vital members and partakers in all realms of life is not a luxury anymore but rather a necessity. Regrettably, gender inequality in Egypt remains to be a fundamental barrier hindering the accomplishment of this goal.

Subsequent to its importance, an immense body of literature is devoted to topics pertaining to gender equality, particularly in developing countries like Egypt. The 'feminist empowerment' model places extensive importance on gender parity and considers gender subservience to be an intricate, multifaceted, deeply rooted problem that adversely impacts all aspects of a woman's existence (Dorlet, 2005). According to Jayachandran (2014) in her paper "The Roots of Gender Quality in Developing Countries," gender disparity is sculpted by economic and cultural influence (cited in Jamila and Muchmudi, 2019). Also, Kabeer - a prominent advocate for women empowerment and gender equality - warns that gender isolation extends beyond the household domain to the public milieu through biased policies and legislation as well as inequitable treatment of officials and employers (Kabeer, 2012).

In addition to its situation as an emerging economy - with all the challenges contingent on that - a host of non-economic factors add to the uniqueness of the situation of Egypt: social, cultural, religious, to name a few. The matter that has drawn the interest of a lot of researchers to focus their work on the case of Egypt. Gender inequality in Egypt has been a subject tackled by many scholars such as Hayat Alvi, who wrote the article "Women's Rights Movements in the Arab Spring" and Farah Gaman Shash who wrote "Gender Quality in a Time of Change" (cited in Jamila and Muchmudi, 2019).

This paper aims to offer a perspective on the current situation of women in Egypt through comparisons with their status in the past and with other neighbouring countries as well as 
with their global standing. In an attempt to reach this end, the paper implies a scrutiny of the literature, proving that Egypt has a remarkable history of gender equality and justice, nevertheless - to the detriment of women - many of those gains acquired in the ancient time have not been reserved to extend to the present generations of Egyptian women.

\section{Findings}

\subsection{Women in Ancient Egypt}

In ancient Egypt discrepancies and inequality in social, legal, economic or any other form of rights was based on social class not gender. The remarkable variation in the status given to ancient Egyptian women can be clearly seen in contrast to ancient Greek women. In 332 B.C. when the Greek invaded Egypt, Egyptian women were enjoying advanced rights and civil liberties in comparison to Greek women living under a male dominated system at that time. Women civil rights in Egypt stretched to all capacities, they could buy, sell, own and manage private assets as well as all forms of possessions including; land, goods, property, slaves and money. This is in addition to settling any legal disputes including; sung, testifying in courts as well as representing themselves in resolving matters pertaining to marriage, divorce and adopting kids. In contrast, it was mandatory for Greek women to have a male figure representing them - husband, brother or father - in any legal matter (Tyldesley, 2017).

Women in ancient Egypt were rendered the most prestigious degrees of respect even by religion, as they were appointed priests and worshiped as Gods with equal standing as male Gods. Egyptian women had the right to procure property through a variety of means, in the form of a gift, inheritance - from husband, parents or any member of her family- or as proceeds and returns on her own investments or employment remittances. Moreover, they were entitled to up to one third of all the shared possessions with her husband that has accumulated prior to their marriage. This is while retaining any property that she has entered the marriage with, all of which has to be reverted to her -in full- in case of a divorce. This is in addition to any settlements postulated in the initial marriage agreement (Tyldesley, 2017).

It can be - therefore justifiably - alleged that ancient Egypt symbolized a righteous era for women. A time where they were secured civil rights not to mention evident privileges compared to most ancient civilizations. Regrettably, these rights have not advanced nor even maintained through the history to our modern times, on the contrary, they have regressed evidently.

\subsection{Overview of the extant situation}

Unfortunately, compared to the eminent position they have held in history, the status of Egyptian women has experienced evident deterioration during the last decades. This is despite some achievements that can't be ignored. In comparison to other countries Egypt ranks manifestly low with regards to gender equality. The Organization for Economic Cooperation and Development's Social Institutions and Gender Index 2014 - specializing in measuring legislation, practices, and attitudes constraining women's civil rights and opportunities, ranks Egypt 'very high' in gender discrimination similar to other African and Middle Eastern countries.

Despite the fact that women make up for almost half of the population the USAID report shows that women have considerably lower involvement in the labour force compared to 
men, with the share of women at $26 \%$ versus $79 \%$ for men. This is also coupled with gender disparities with regards to literacy rates (USAID, 2017).

On a more positive note, the general life expectancy in 2016 has increased registering 71.48 years causing an improvement in Egypt's position among the 192 countries -reported by the World Bank- from 113 in 2015 to 112 in 2016. Life expectancy of females in 2016 has been reported at 73.73 years as opposed to 69.3 years for men (Trading Economics, 2017). According to the Central Agency for Public Mobilization and Statistics (CAPMAS) life expectancy of females at birth improved to 73.6 years in 2017 as opposed to 70.8 years for males. It is worthy to note here that life expectancy in 2006 has been reported to be 69.1 years for females and 66.5 years for males. CAMPAS also postulates that in $201746.9 \%$ females have been found to be members or recipients of health insurance in comparison, however, to $54.6 \%$ male beneficiaries (Samir, 2018).

It's important to note here that in order to meticulously assess the extant situation pertaining to gender disparity in Egypt in comparison to neighbour countries a number of imperative indices need to be employed. The following section of the paper will therefore display data presented in the Global Gender Gap Index (GGI) as well as the Gender Gap index of MENA region, the Gender Inequality Index (GII), and finally Gender Development Index (GDI).

The Global Gender Gap Index (GDI) was first launched by the World Economic Forum in 2006 to establish a base for identifying the extent of gender discrepancies. For 14 years the Global Gender Gap Index has offered a trajectory for the progression of different countries over time whether positively or negatively. The GDI assesses the gap between men and women in four principal classifications. These are -as shown in Table 1- Economic Participation and Opportunity, Educational Attainment, Health and Survival and Political Empowerment. The highest possible score is 1 indicating the ultimate equality, and the lowest possible score is 0 indicating the utmost inequality (WEF, 2020).

Table 1. Global Gender Gap Index for Egypt in 2017

\begin{tabular}{|l|c|c|c|c|c|c|}
\hline & Rank & GGI & $\begin{array}{c}\text { Average } \\
\text { Value }\end{array}$ & Women & $\begin{array}{c}\text { Men } \\
\begin{array}{l}\text { Comparison } \\
\text { to Men }\end{array}\end{array}$ \\
\hline $\begin{array}{l}\text { Economic participation and } \\
\text { opportunity }\end{array}$ & $\mathbf{1 3 5}$ & $\mathbf{0 . 4 1 3}$ & 0.585 & - & - & - \\
\hline Labour Force Participation & 138 & 0.310 & 0.667 & 24.9 & 80.4 & 0.31 \\
\hline Wage Equality for Similar Work & 58 & 0.664 & 0.634 & - & - & 0.66 \\
\hline Estimated Earned Income (USD, PPP) & 131 & 0.285 & 0.509 & 4,911 & 17,215 & 0.29 \\
\hline $\begin{array}{l}\text { Legislators, Senior Officials, and } \\
\text { Managers }\end{array}$ & 122 & 0.069 & 0.32 & 6.4 & 93.6 & 0.07 \\
\hline Professional and Technical Workers & 106 & 0.601 & 0.758 & 37.5 & 62.5 & 0.60 \\
\hline Education attainment & $\mathbf{1 0 4}$ & $\mathbf{0 . 9 6 0}$ & 0.953 & & & \\
\hline Literacy Rate & 113 & 0.813 & 0.883 & 67.2 & 82.6 & 0.81 \\
\hline Enrolment in Primary Education & 1 & 1.000 & 0.979 & 98.4 & 97.7 & 1.01 \\
\hline Enrolment in Secondary Education & 1 & 1.000 & 0.971 & 82.5 & 81.3 & 1.01 \\
\hline Enrolment in Tertiary Education & 96 & 0.964 & 0.938 & 35.6 & 36.9 & 0.96 \\
\hline Health and Survival & $\mathbf{9 9}$ & $\mathbf{0 . 9 7 1}$ & 0.956 & & & \\
\hline Sex Ratio at Birth & 110 & 0.943 & 0.92 & - & - & 0.94 \\
\hline Healthy Life Expectancy & 105 & 1.033 & 1.037 & 63.2 & 61.2 & 1.03 \\
\hline Political Empowerment & $\mathbf{1 1 9}$ & $\mathbf{0 . 0 8 7}$ & 0.227 & & & \\
\hline Women in Parliament & 107 & 0.176 & 0.279 & 14.9 & 85.1 & 0.18 \\
\hline Women in Ministerial Positions & 104 & 0.133 & 0.209 & 11.8 & 88.2 & 0.13 \\
\hline $\begin{array}{l}\text { Years with Female Head of State } \\
\text { (Last 50) }\end{array}$ & 69 & 0.000 & 0.2 & 0.0 & 50.0 & 0.00 \\
\hline
\end{tabular}

Source: JICA (2018) 
In 2015 the Global Gender Gap Index has placed Egypt at 136 out of 145 countries across the world (USAID, 2017). This is while the same investigation in 2017 asserts that the Gender Gap Index (GGI) for Egypt is 0.608 placing it as number 144 out of 144 nations. Amid the four classifications used in the report as a criterion are the low levels of 'economic participation' and 'political empowerment' as well as access to employment opportunities. The comparison between 2006 -when the index was first introduced- and 2017 indexes show a degree of progression in political involvement however no change is detected with respect to economic participation and opportunities (JICA, 2018). It's worthy to note here that in the 2020 GGI Egypt has a score of 0.629 placing it as number 134 out of 153 countries and resulting in humble yet positive 0.051 compared to the 2006 score (World Economic Forum, 2020).

Taking a closer look to compare gender disparity in Egypt with its neighbouring countries, the World Economic Forum report reviewing the status of women in the Middle East and North Africa in 2020 rates Egypt as number 7 out of 18 countries in the region and number 135 out of 159 constituting the report (World Economic Forum, 2020). Although not a desirable position, it is still considered an improvement compared to the same report in 2010 when Egypt ranked 125 relative to 134 countries constituting the Gender Equality Profile for that year and had the 12th position among the 15 MENA countries reviewed on the same year (UNICEF, 2011).

Table 2. Gender Gap Index (MENA Region)

\begin{tabular}{|l|c|c|c|}
\hline \multirow{2}{*}{ Country } & \multicolumn{2}{|c|}{ Rank } & \multirow{2}{*}{ Score } \\
\cline { 2 - 3 } & Regional & Global & \\
\hline United Arab Emirates & 1 & 120 & 0.655 \\
\hline Kuwait & 2 & 122 & 0.650 \\
\hline Tunisia & 3 & 124 & 0.644 \\
\hline Turkey & 4 & 130 & 0.635 \\
\hline Algeria & 5 & 132 & 0.634 \\
\hline Bahrain & 6 & 133 & 0.629 \\
\hline Egypt & $\mathbf{7}$ & $\mathbf{1 3 4}$ & $\mathbf{0 . 6 2 9}$ \\
\hline Qatar & 8 & 135 & 0.629 \\
\hline Jordan & 9 & 138 & 0.623 \\
\hline Mauritania & 10 & 141 & 0.614 \\
\hline Morocco & 11 & 143 & 0.605 \\
\hline Oman & 12 & 144 & 0.602 \\
\hline Lebanon & 13 & 145 & 0.599 \\
\hline Saudi Arabia & 14 & 146 & 0.599 \\
\hline Iran & 15 & 148 & 0.584 \\
\hline Syria & 16 & 150 & 0.567 \\
\hline Iraq & 17 & 152 & 0.530 \\
\hline Yemen & 18 & 153 & 0.494 \\
\hline
\end{tabular}

Source: WEF (2020): The Global Gender Gap Report (rankings of 153 countries).

The Gender Inequality Index (GII) was established by the United Nations in the 2010 Human Development Report. The index examines gender disparities based on three basic aspects: reproductive health, empowerment, and economic activity. 'Reproductive health' is determined by maternal mortality and adolescent birth rates. 'Empowerment' is determined by the number of parliamentary seats retained by women and completion of secondary and higher education by each gender. This is while 'economic activity' is determined by participation in the labour market for women versus men. As such, the GII can be explained as the shortfall in human development resulting from the disparity in the male/female accomplishments with regards to the three mentioned aspects (UNDP, 2019). 
The Gender Inequality Index (GII) for Egypt has registered the value of 0.565 in 2015 placing it at 135 amongst 159 nations. Table 3 shows that despite the improvement in the country's index for reproductive health, the indexes for labour force involvement, number of seats in the parliament, various economic activity as well as women empowerment in general are found to be evidently low. In comparison to its Arab neighbour Morocco for instance, it is reported that the 'adolescent birth rate' as well as the disparity in 'education' is clearly higher (JICA, 2018).

Table 3. Egypt's GII in Comparison with Other Countries

\begin{tabular}{|l|c|c|c|c|c|c|c|c|c|}
\hline & \multirow{2}{*}{$\begin{array}{c}\text { GII } \\
\text { Value }\end{array}$} & $\begin{array}{c}\text { GII } \\
\text { Rank }\end{array}$ & $\begin{array}{c}\text { Maternity } \\
\text { Mortality } \\
\text { Rate (i) }\end{array}$ & $\begin{array}{c}\text { Adolescent } \\
\text { Birth Rate } \\
\text { (ii) }\end{array}$ & $\begin{array}{c}\text { Female } \\
\text { Seats in } \\
\text { Parliament } \\
(\%)\end{array}$ & $\begin{array}{c}\text { Populating with } \\
\text { at least } \\
\text { Secondary } \\
\text { Education (\%) }\end{array}$ & \multicolumn{2}{|c|}{$\begin{array}{c}\text { Labour Force } \\
\text { Participation } \\
\text { rate (\%) }\end{array}$} \\
\cline { 7 - 11 } & & & & Women & Men & Women & Men \\
\hline Egypt & $\mathbf{0 . 5 6 5}$ & $\mathbf{1 3 5}$ & $\mathbf{3 3}$ & $\mathbf{5 1 . 9}$ & $\mathbf{2 . 2}$ & $\mathbf{5 4 . 5}$ & $\mathbf{6 8 . 2}$ & $\mathbf{2 2 . 8}$ & $\mathbf{7 6 . 1}$ \\
\hline Morocco & 0.494 & 113 & 121 & 31.7 & 15.7 & 25.7 & 33.2 & 25.3 & 74.3 \\
\hline Syria & 0.554 & 133 & 68 & 39.4 & 12.4 & 34.8 & 43.4 & 12.2 & 70.8 \\
\hline $\begin{array}{l}\text { Arab } \\
\text { States }\end{array}$ & 0.535 & - & 142 & 47.7 & 15.5 & 41.6 & 52.3 & 22.3 & 75.1 \\
\hline $\begin{array}{l}\text { Medium } \\
\text { HDI }\end{array}$ & 0.491 & - & 164 & 40.8 & 19.9 & 40.4 & 57.6 & 37.2 & 79.4 \\
\hline
\end{tabular}

Source: UNDP (2016): Briefing Note for Countries on the 2016 Human Development Report: Egypt (i) Maternal mortality ratio is expressed in number of deaths per 100,000 live births and (ii) adolescent birth rate is expressed in number of births per 1,000 women ages 15-19.

The GDI is a new measure that has been introduced in 2014, centred around the 'sexdisaggregated' data provided by the Human Development Index, which is an average gauge of fundamental human development attainments in a country. Similar to all averages, the HDI conceals the disproportionate distribution of these attainments in a given society, the matter that gives the Gender Development Index its significance. The GDI examines gender disparities signifying three fundamental determinants of HDI: 'health', indicated by female and male life expectancy at birth; 'education', indicated by female and male anticipated years of schooling for kids, 'mean years of schooling' for adults aged 25 years and older, as well as command over economic resources, depicted by female and male estimated 'GNI per capita'. It is calculated based on 166 countries grouped in five distinct groups reflecting the extent of divergence from the gender equality of the HDI, therefore, GDI can be regarded as a ratio of female to male HDI (UNDP, 2019).

Unfortunately, subsequent to its evident aberration from the gender equality of Human Development Index (HDI) Egypt's position in the Gender Development Index (GDI) has retreated to 0.884 in 2015 placing it amongst the lowest five clusters in the GDI (Table 4). This is despite the noticeable improvement in the education realm compared to its neighbouring countries (JICA, 2018). Similar values have also been indicated in 2018 where women HDI figures for Egypt rested on 0.643 as opposed to 0.732 for men, resulting in a GDI value of 0.878 which still positions Egypt in the same category (UNDP, 2019).

Finally, with respect to the Sustainable Development Goals (SDGs) the same report provides that Egypt's index score is 64.9 grading it 87 out of 157 countries. The indicators and the level of attaining them are specifically geared towards gender equity together with girls/women empowerment. Midst the 17 SDGs, the country's performance on battling hunger (SDG2), gender equality regarding women's labour opportunities and political participation (SDG5), and economic growth and decent work (SDG8) is comparatively very low (JICA, 2018). 
Table 4. Egypt's Gender Development Index (GDI) in Comparison to Other Countries

\begin{tabular}{|l|c|c|c|c|c|c|c|c|c|c|c|}
\hline & \multicolumn{2}{|c|}{$\begin{array}{c}\text { Life } \\
\text { expectancy }\end{array}$} & \multicolumn{2}{c|}{$\begin{array}{c}\text { Expected Years } \\
\text { of Schooling }\end{array}$} & \multicolumn{2}{c|}{$\begin{array}{c}\text { Mean Years of } \\
\text { Schooling }\end{array}$} & \multicolumn{2}{c|}{ GNI per Capita } & \multicolumn{2}{c|}{ HDI Values } & GDI \\
\hline & Women & Men & Women & Men & Women & Men & Women & Men & Women & Men & \\
\hline Egypt & $\mathbf{7 3 . 6}$ & $\mathbf{6 9 . 2}$ & $\mathbf{1 3 . 0}$ & $\mathbf{1 3 . 2}$ & $\mathbf{6 . 4}$ & $\mathbf{7 . 9}$ & $\mathbf{4 , 7 5 0}$ & $\mathbf{1 5 . 2 6 7}$ & $\mathbf{0 . 6 4}$ & $\mathbf{0 . 7 2 4}$ & $\mathbf{0 . 8 8 4}$ \\
\hline Morocco & 75.3 & 73.3 & 11.5 & 12.6 & 3.8 & 6.4 & 3,388 & 11.091 & 0.579 & 0.7 & 0.826 \\
\hline Syria & 76.6 & 63.9 & 8.9 & 9.0 & 4.6 & 5.6 & 835 & 4,007 & 0.475 & 0.558 & 0.851 \\
\hline $\begin{array}{l}\text { Arab } \\
\text { states }\end{array}$ & 72.8 & 69.1 & 11.4 & 12.1 & 5.9 & 7.6 & 5,455 & 23,810 & 0.621 & 0.726 & 0.856 \\
\hline $\begin{array}{l}\text { Medium } \\
\text { HDI }\end{array}$ & 70.4 & 66.8 & 11.5 & 11.3 & 5.6 & 7.8 & 3,314 & 9,131 & 0.582 & 0.668 & 0.871 \\
\hline
\end{tabular}

It remains to be indicated that the position of women in Egypt is evidently predisposed by the vague standing of the state where women issues are concerned. This includes the states position and reactions regarding women organizations, the expansion of the civil society, international expectations and the compressions they entail; especially those imposed by donor organizations and last but not least, the evident increase in the influence of the conservative Islamists (Al-Ali, 2002, cited in Dorlet, 2005). Saadallah (2001) cited in Dorlet (2005) adds to the previous list the importance of emergence of political Islam, the progression of societal Islamization as well as the patriarchy dynamics. It is needless to say that all the mentioned play an influential role in shaping and portraying the status of women in Egypt, unfortunately not to the best of their interests.

The following section will attempt a more thorough overview of the status of women in Egypt with a more in-depth examination of indicators affecting their capability to fulfil the crucial role they should be playing in attaining the desired economic growth/development. This would customarily include matters pertaining to an array of pointers; namely health, education, legal rights, political participation, access to economic resources, labour opportunities, and levels of empowerment in general. However, this paper concentrates on two closely intertwined features influencing the status of women in Egypt, the political participation of women and the legal rights as portrayed by law. This is since women participation in the political arena paves the way to passing as well as enforcing legislation that endorses women rights in different realms.

\subsection{The political setting in Egypt}

Egypt has been run as a presidential system since 1952 following the 1952 revolution that marked the end of the monarchy and the birth of the new independent Arab republic of Egypt. In the recent years, the country has had its share of turbulence and unrest during its post-revolution period, precisely between 2011 and 2013. Since then the state has implemented a new constitution, assumed a single legislature (the parliament) and elected two presidents. Egypt has since been enjoying a state of relative political stability allowing the administration to concentrate on economic reform as a national priority.

By virtue of the current constitution the president has the right to serve for two consecutive terms of four years each. The prime minister is appointed by the president pending the approval of the house of representatives (parliament). The house of representatives is one chamber ('unicameral'), it hosts 596 members three quarters of which must be elected directly. The remaining quarter constituting 120 seats is reserved to women and minorities elected through a 'party list system', in addition to 28 seats appointed by the president. Members of the house of representatives serve for 5 years, the last election took place in 2015 where $41 \%$ of the seats were shared among three parties while a majority of $59 \%$ won by independent individuals (Oxford Business Group, 2018). 


\subsection{Women's participation in the political milieu}

Egyptian women have a long history of partaking in the political milieu amid all the encounters and adversities that faced the country through the years. Women's evident participation in the political life goes back to the 1919 revolution when they took out to the streets side by side with men facing the same danger and giving the same sacrifices. The role they played gave rise -few years afterwards- to what became to be known as the 'feminist activism' followed by the Egyptian feminist Union in 1923 (Al-Ali, 2002 cited in Dorlet, 2005). The feminist activists demanded better political rights for women, adjustments in the personal status law -particularly in stipulations pertaining to divorce and polygamy- and allowing women fair chance for professional job opportunities. The efforts of this generation of feminists was trailed by the exertions of others in early 1950s when the bourgeois women of the country merged with the middle class in founding new associations that became more persistent in requesting equal opportunities in all professions and demanding better integration of women in all realms including the political one (Hatem, 1994 cited in Dorlet, 2005).

Regrettably, despite their diligent commitment and full-fledged support to all the country's causes through the history, Egyptian women have been underrepresented in the political life for the most part. Similar to the challenges they face amid their participation in the economic realm, Egyptian women encounter substantial difficulty into accessing the political arena. Even after the vital role they played in two revolutions (2011 and 2013), political participation still remains an aspect of gender acceptance.

The right to vote and participate in elections has been granted to women by law in 1956 . Despite that women participation in the political life has remained extremely humble up to the 2011 revolution. For instance, as of 2007 women share of the People's Assembly (the Egyptian Parliament) has been a timid 2\% of the total seats. In order to rectify this situation a law has been postulated in 2009 specifying a quota for women allowing better representation in the People's Assembly (UNICEF, 2011).

The 2014 Constitutions has made a sincere attempt into granting women a more just opportunity in participating in the political scene. The Constitution visibly stipulates that the government is dedicated to putting in effect all the required actions to guarantee an adequate representation of women in the parliament (Article 11). This is in addition to designating one-quarter of the seats in local councils for women (Article 80).

It's worth noting that at the present - amid the 2015 parliamentary elections - women are in possession of 89 seats in the parliament out of a total of 568 seats, which amounts to $14.9 \%$. The stated percentage indicates an evident improvement compared to the 2010 parliamentary elections registering $12.7 \%$ for women and from that of 2012 as well-during the Muslim Brotherhood rule - registering 2.2\% (JICA, 2018).

Table 5. Women Participation in Political Posts

\begin{tabular}{|c|c|}
\hline Women's Seats in the National Parliament & 89 seats (14.9\% in 2015 elections) \\
\hline Female Cabinet Members & 6 members (17.1\% in January 2018) \\
\hline Women's Seats in the Local Council & $\begin{array}{c}\text { Supposed to be 25\% (to be confirmed after } 2019 \\
\text { elections) }\end{array}$ \\
\hline Women's Governors & 1 person (3.7\% appointed in 2017) \\
\hline
\end{tabular}

Source: compiled based on JICA (2018). 
The 2015 parliamentary elections have witnessed unpresented female representation. In the named election 100 women have run as candidates through eight party lists while 110 other women have run as independents amounting to $8.2 \%$ of total candidates. This is in addition to 75 women who have been directly elected as well as 14 who have been appointed by the president. As such, it can be undoubtedly stated that the 2015 parliamentary elections have displayed the most prevalent women representation in the history of Egypt (ECWR, 2015).

As for ministerial appointments, for the first time in Egypt's Cabinet history eight women have been appointed as ministers. This is as two new ministers were appointed as part of the ministerial reshuffle in January 2018 to head the Ministry of Planning and the Ministry of Health. This is in addition to the six - previously appointed - female ministers heading the Ministries of Culture, Tourism, Investment, Environment, Social Solidarity, and Migration, all together accounting for $17.1 \%$ of the cabinet.

As such, the percentage of women holding higher managerial positions in the Government - since 2015- as ministers has registered 4.9\%, deputy Minister 0\%, higher executive $10.7 \%$, high executive $14 \%$ and general manager 9.3\% (JICA, 2018). Also, according to the ECWR (2018), 21.3\% of the Ministry of Foreign Affairs personnel are women holding consular and diplomatic positions up to the title of Consular General and Ambassador to Egypt. This is in addition to appointing the first female governor in Egypt - in February 2017- to head the Beheria Governorate (ECWR, 2018).

As humble as these percentages may seem - when compared with international statistics for women political involvement - they still signify an evident improvement compared to the prior situation in Egypt. That being said, a lot still needs to be accomplished to secure women their fair opportunity of sound participation in political life.

The judicial system - however - has not experienced the same progression. Despite the fact that the constitution plainly stipulates the women's right to be appointed in 'judicial bodies and entities' - including heading courts - without any discernment, the state council still refuses to appoint female judges (ECWR, 2018). Until 2007 it has not been permissible for women to be appointed as judges. Subsequent to years of fighting and petitioning -by women's organizations and advocates- the prohibition has been hauled up; 30 women have been appointed as judges prior to the decision. Female judges, however, remain to be confined to family courts and denied any access to penal courts. Moreover, the State Council -which is the highest administrative court in the country- has ruled in 2010 to ban women from being appointed to the council. Although, the decree has been overruled by the Constitutional Court, women are still denied appointment to the State Council and also remain to be extremely underrepresented in the judicial system in general (UNICEF, 2011).

\subsection{The current legal standing of women}

The Egyptian law draws its foundation from the French civil decrees and the Islamic jurisprudence (Shari'a). The Personal Affairs Law, however, attending to matters pertaining to marriage, divorce, alimony and child custody rules by Shari'a. Almost in all legal disputes the court will view men and women equally except when it comes to family laws where a woman's testimony is worth half that of a man (UNICEF, 2011). It's important to know that the Coptic Christians of Egypt - constituting 10\% of the population - are governed by their religious laws when it comes to the named family matters. As such in matters pertaining to Personal Law - which primarily impacts women - a unified law that oversees all Egyptians does not exist. 
Having the state acknowledge the importance of incorporating a 'feminist agenda' in the legal framework has been the result of diligent and persistent exertions of countless feminist organizations. In 1960s with the conversion of Egypt into socialism, policies intending to alter women legal standing started to be introduced and enforced (Hatem 1994, cited in Dorlet, 2005). The new 1956 constitution granted women voting rights, endorsed their right to education at all levels as well as their right to work outside the household (Al-Ali, 1997, cited in Dorlet, 2005). As such women rights to health, education, and employment finally became protected by virtue of law. The legal context for women rights, however, has progressed through the recent years even more. The constitution that has been established and enforced in 2014 has designated a number of articles to enhancing the current situation of women especially in rural areas.

Article 9 of the constitution denounces discrimination against women in all its forms and institutes the foundation for equal opportunity for all Egyptians regardless of gender. Article 11 concedes the duty and responsibility of the state to guarantee equitable treatment for men and women as far as accessing civil, economic, social as well as cultural rights are concerned. The article also attempts to facilitate the enactment of methods aiming to secure the proper representation of women in civil institutions and different decision-making associations. This is in addition to banning gender discrimination and protecting women against all practices of violence. Moreover, the article also stipulates the state's commitment to extend assistance and security to mothers and their children, females heading and supporting households, elder women as well as those in dire need (UN Women, 2018).

There are also a number of other articles in the constitution that prohibits violence against women, one of which is article 98 that incriminate all practices of slavery and trafficking in humans especially women and minors. Moreover, the constitution also elevates the minimum legal age for marriage to 18 years in an attempt to restrain child marriage, a problem prevalent especially in rural areas and upper Egypt (UN Women, 2018).

Lastly, Article 93 of the constitution stipulates for Egypt's obligation towards human rights resolutions specially those pertaining to women rights. Further amendments have been also implemented to enhance gender equity, the most imperative of which are the adjustments to the inheritance rights. The revised law incriminates any hindrance to a woman's rights to attain her inheritance and declares it a crime punished by a fine of up to 100,000 Egyptian pounds and a jail sentence of a minimum of 6 months (UN Women, 2018).

Furthermore, the government of Egypt has made promoting women's rights and raising the awareness to the vitality of their inclusion in all aspects of life a matter of highest importance. This goal has been validated at the highest political level as manifested by the government's decision to declare 2017 to be the "Year of Egyptian Women". It is, however, needless to point out that as important as changing the legislation is it cannot attain the desired outcomes on its own. As honourable as the intentions and goals are the implementation on real grounds remains to face numerous challenges, starting from administrative, social and cultural - to name a few - to the frail enforcement of the legislation itself. 


\section{Conclusion}

The status of Egyptian women in ancient times is unparallel to any other civilization as they have enjoyed equal legal, political, social and economic rights as men. Unfortunately, this exceptional position has not been maintained through the history, on the contrary, it has regressed substantially. Currently, Egypt rates among the highest countries in the world with respect to gender inequality as indicated by Gender Inequality Index (GII), the Global Gender Gap Index (GGI) and Gender development Index (GDI). Egypt - at present - is an emerging economy facing immense economic as well as social challenges. Women amount for almost half of the country's population, continuing to marginalize them as such is a waste of resources that can otherwise alter the social as well as economic wellbeing of the country. Little, however, can be achieved if women are not perceived as crucial partakers in achieving these goals. Gender disparities, as such, do not only deny women their civil rights -as postulated by the law- but poses an impediment towards their empowerment.

Achieving women empowerment is widely recognized as a prerequisite to development, the matter that is patently acknowledged by the Egyptian administration. Needless to say that the success of the government's alleged reforms is contingent on its ability to tackle obstacles hindering growth and development potentials, an essential one of which being women active involvement in all realms to ensure the well-being of the country. Gender conscious legal standing as well as proper participation in the political arena are among the most crucial rudiments of such involvement. Despite the government's sincere exertions in founding legislations that endorses improved women rights and supporting better political participation opportunities for them, a lot remains to be sought in order for Egyptian women participation to reach the global percentages. Thus, gender equality is not just crucial for attaining social justice but also for achieving various social and economic goals on the road of accomplishing development in its true sense.

\section{References:}

Dorlet, J. (2005): Women and Micro Credit: Towards an Understanding of Women's Experiences in Cairo, Egypt. [online] Digitool.library.mcgill.ca. Available at: http://digitool.library.mcgill.ca/webclient/StreamGate?folder_id=0\&dvs=1557671339689 444\&u sePid1=true\&usePid2=true [Accessed 12 May 2019].

ECWR (2015): Steps Backward: Parliamentary Representation alone is not enough Women's Status Report Summary 2015 Summary.pdf. [online] Available at: https://drive.google.com/file/d/0BwsERZCDkJWYT2pjdHIEM0xOTHM/view?ts=572b3526\&pre $\mathrm{f}=2 \&$ pli $=1$ [Accessed 12 May 2019].

ECWR (2018): 2017 Report on the Egyptian Women Status Summary 2015 Summary.pdf. [online] Ecwronline.org. Available at: http://ecwronline.org/wp-content/uploads/2018/04/EnglishSummary-the-2017-Womens-Status-Report.pdf [Accessed 13 May 2019].

Jamilah, M., Machmudi, Y. (2019): Political Gender Inequality in Egypt after the Arab Spring (2011-2013). [online] Advances in Social Science, Education and Humanities Research, volume365. Available at: http://creativecommons.org/licenses/by-nc/4.0/ [Accessed 10 Jan. 2020].

Japan International Cooperation Agency (JICA) (2018): Country Gender Profile, Arab Republic of Egypt Survey Report, 2018. Open jicareport.jica.go.jp. (2018). [online] Available at: http://open_jicareport.jica.go.jp/pdf/12305181.pdf.

Kabeer, N. (2012): Women's economic empowerment and inclusive growth: labor markets and enterprise development. [online] Idrc.ca. Available at:

https://www.idrc.ca/sites/default/files/sp/Documents\%20EN/NK-WEE-Concept-Paper.pdf 
Oxford Business Group (2018): The Report: Egypt 2018. [online] Oxford Business Group. Available at: https://oxfordbusinessgroup.com/egypt-2018 [Accessed 18 Oct. 2018].

Samir, N. (2018): 73.6 average female life expectancy in Egypt in 2017: CAPMAS - Daily News Egypt. [online] Daily News Egypt. Available at: https://dailynewsegypt.com/2018/05/27/73-6average-female-life-expectancy-in-egypt-in-2017-capmas/.

Tradingeconomics.com (2017): Egypt Population Female Percent Of Total. [online] Available at: https://tradingeconomics.com/egypt/population-female-percent-of-total-wb-data.html.

Tyldesley, J. (2017): The Status of Women in Egyptian Society | Middle East \& Islamic Studies Collection. [online] Middleeast.library.cornell.edu. Available at:

https://middleeast.library.cornell.edu/content/status-women-egyptian-society.

UNICEF (2011): Egypt MENA Gender Equality Profile Status of Girls and Women in the Middle East and North Africa. Reginal Office for the Middle East and Africa. Available at:

https://www.unicef.org/gender/files/Egypt-Gender-Eqaulity-Profile-2011.pdf.

USAID (2017): Gender Equality and Women's Empowerment | Egypt | U.S. Agency for International Development. [online] Available at: https://www.usaid.gov/egypt/gender-equalityand-womens-empowerment.

UN Women (2018): Egypt. Profile of Rural Women. Egypt Country Office UN Women, Cairo. [online] Available at: http://egypt.unwomen.org/en/digital-library/publications/2018/05/profile-ofrural-women.

UNDP (2019): Inequalities in Human Development in the 21st Century Briefing note for countries on the 2019 Human Development Report, Egypt. [online] Hdr.undp.org. Available at: http://hdr.undp.org/sites/all/themes/hdr_theme/country-notes/EGY.pdf [Accessed 6 Jan. 2020].

World Economic Forum (2020): Global Gender Gap Report 2020. [online] Www3.weforum.org. Available at: http://www3.weforum.org/docs/WEF_GGGR_2020.pdf [Accessed 7 Jan. 2020]. 